\title{
The receiver operating characteristics curve in the evaluation of a random urine specimen as a screening test for diabetic nephropathy ${ }^{1}$
}

\author{
Themis Zelmanovitz ${ }^{2}$, Jorge L. Gross ${ }^{2}$, Jarbas L. Oliveira², Alexandre \\ Paggi $^{2}$, Mariana Tatsch ${ }^{2}$, Mirela J. Azevedo
}

OBJECTIVE: To assess the performance of measurements of urinary albumin concentration and urinary albumin-to-creatinine ratio in diurnal random urine specimen for the screening of diabetic nephropathy.

PATIENTS AND METHODS: A total of 95 ambulatory NIDDM patients (49 women, ages 40-75 years) collected 123 random urinary specimens during the morning after completing a timed 24-h urine collection. Albumin was measured by immunoturbidimetry. According to timed urinary albumin excretion rate measured in the 24-h collection (criterion standard), samples were classified as normoalbuminuric (urinary albumin excretion rate $<20 \mu \mathrm{g} / \mathrm{min} ; n=54$ ), microalbuminuric (urinary albumin excretion rate $20-200 \mu \mathrm{g} / \mathrm{min} ; n=44$ ), and macroalbuminuric (urinary albumin excretion rate $>200 \mu \mathrm{g} / \mathrm{min} ; n=25$ ). The receiver operating characteristics curve approach was used. The receiver operating characteristics curves of urinary albumin concentration and urinary albumin-to-creatinine in random urine specimen for screening of microalbuminuria (normo- and microalbuminuric samples; $n=98$ ) and macroalbuminuria (micro- and macroalbuminuric samples; $n=69$ ) were plotted.

RESULTS: Spearman's coefficients of correlation of 24-h urinary albumin excretion rate vs. urinary albumin concentration and urinary albumin-to-creatinine ratio were 0.91 and 0.92, respectively $P<0.001$ ). The calculated areas $( \pm S E)$ under the receiver operating characteristics curves to screen microalbuminuria for urinary albumin concentration (0.9766 \pm 0.015$)$ and urinary albumin-to-creatinine ratio $(0.9689 \pm 0.014)$ were similar $P>0.05)$ as were the corresponding areas of microalbuminuria $(0.9868 \pm 0.0094$ and $0.9614 \pm 0.0241$, respectively; $\mathrm{P}>0.05)$. The first point with $100 \%$ sensitivity and the point of intersection with a $100 \%$-to100\% diagonal for microalbuminuria were as follows: 16.9 and $33.6 \mathrm{mg} / \mathrm{l}$ for urinary albumin concentration, and 15.0 and $26.8 \mathrm{mg} / \mathrm{g}$ for urinary albumin-to-creatinine ratio; for macroalbuminuria, 174.0 and $296.2 \mathrm{mg} / \mathrm{l}$ for urinary albumin concentration, and 116.0 and $334.3 \mathrm{mg} / \mathrm{g}$ for urinary albumin-to-creatinine ratio, respectively.

CONCLUSIONS: Albumin measurements (urinary albumin concentration and urinary albumin-to-creatinine ratio) in a random urine specimen presented almost perfect accuracy for the screening of micro- and macroalbuminuria; urinary albumin concentration measured in a random urine specimen is simpler and less expensive than urinary albumin-to-creatinine ratio and urinary albumin excretion rate. It is suggested as a valid test for use in screening for diabetic nephropathy.

Key-words: Diabetic nephropathy; urinary albumin concentration; urinary albuminto-creatinine ratio.

\footnotetext{
Este artigo foi publicado originalmente em Diabetes Care 1997;20:516-9.

Departamento de Endocrinologia, Hospital de Clínicas de Porto Alegre, Porto Alegre, RS Brasil.

Correspondência: Dr. Jorge Luiz Gross, Rua Ramiro Barcellos 2350, sala 2030, CEP 90035-003, Porto Alegre, RS,

Brasil.Email: gross@hotnet.net
} 


\section{A curva de características operacionais do receptor na avaliação de amostra aleatória de urina como forma de triagem para nefropatia diabética}

OBJETIVO: Avaliar a aplicabilidade das medidas de concentração de albumina urinária e da relação entre albumina:creatinina urinária em amostras aleatórias diurnas de urina como método para a triagem de nefropatia diabética.

PACIENTES E MÉTODOS: Foram coletadas 123 amostras aleatórias de urina de um total de 95 pacientes ambulatoriais DMDI (49 mulheres, idade 40-75 anos), durante a manhã, após o término da coleta de urina de $24 \mathrm{~h}$. A albumina foi medida por imunoturbidimetria. De acordo com a taxa de excreção urinária de albumina obtida na coleta de $24 \mathrm{~h}$ (critério padrão), as amostras foram classificadas como normoalbuminúricas (taxa de excreção urinária de albumina $<20 \mu \mathrm{g} / \mathrm{min} ; \mathrm{n=54}$ ), microalbuminúricas (taxa de excreção urinária de albumina 20-200 $\mu \mathrm{g} / \mathrm{min} ; n=44$ ) e macroalbuminúricas (taxa de excreção urinária de albumina > $200 \mu \mathrm{g} / \mathrm{min} ; n=25)$. O método da curva de características operacionais do receptor foi utilizado. Foram traçadas as curvas de características operacionais do receptor para a concentração urinária de albumina e para a relação albumina:creatinina urinária, a partir de amostras aleatórias de urina; estas curvas foram empregadas para a triagem de microalbuminuria (amostras normo e microalbuminúricas; $n=98$ ) e para a triagem de macroalbuminúria (amostras micro e macroalbuminúricas; $n=69$ ). RESULTADOS: Os coeficientes de correlação de Spearman para a taxa de excreção urinária de albumina de $24 h$ vs. concentração urinária de albumina e vs. relação albumina:creatinina urinária foram 0,91 e 0,92, respectivamente $(\mathrm{P}<0,001)$. As áreas calculadas $( \pm E P)$ abaixo da curva de características operacionais do receptor para concentração urinária de albumina $(0,9766 \pm$ 0,015) e para a relação albumina:creatinina urinária $(0.9689 \pm 0,014)$, utilizadas na triagem de microalbuminuria, foram semelhantes $(\mathrm{P}<\overline{0,05})$. Estas áreas também foram semelhantes para macroalbuminuria $(0,9868 \pm 0,0094$ e 0,9614 $\pm 0,0241$, respectivamente; $\mathrm{P}>0,05)$. O primeiro ponto com sensibilidade de $100 \%$ e o ponto de intersecção com uma diagonal de $100 \%$-a-100\% para microalbuminuria foram os seguintes: 16,9 e 33,6 mg/l para a concentração urinária de albumina, e 15,0 e 26,8 mg/g para a relação albumina:creatinina urinária; para macroalbuminuria, 174,0 e 296,2 mg/l para a concentração urinária de albumina, e 116,0 e 334,3 mg/g para a relação albumina:creatinina urinária, respectivamente.

CONCLUSÕES: As medidas de albumina (concentração urinária de albumina e relação albumina:creatinina uinária) feitas a partir de amostras aleatórias de urina indicaram uma precisão quase perfeita na triagem de micro e macroalbuminúria; medir a concentração urinária de albumina em amostras aleatórias de urina é mais simples e mais barato do que medir a relação albumina:creatinina urinária e a taxa de excreção urinária de albumina. Sugerese que o teste é válido para a triagem de nefropatia diabética.

Unitermos: Nefropatia diabética;concentração urinária de albumina; relação albumina:creatinina urinária. 


\section{Introduction}

The screening for diabetic nephropathy has become increasingly relevant since it is the most common cause of end-stage renal failure in the United States (1). It is also associated with increased cardiovascular morbidity and mortality, especially in NIDDM patients $(2,3)$. From a clinical perspective, diabetic nephropathy has two distinct but interconnected stages: incipient nephropathy; or microalbuminuria; and overt nephropathy, or macroalbuminuria. The microalbuminuria phase is characterized by potential reversibility if proper therapeutic measures are used. Macroalbuminuria is a more advanced stage with a progressive, virtually inexorable, decline in renal function (4). This difference - potential reversibility - makes the possibility of identifying the disease stage upon screening a very useful tool for immediate intervention. Urinary albumin excretion is the main parameter used to diagnose both incipient and overt diabetic nephropathy $(5,6)$. A timed urine collection, either $24 \mathrm{~h}$ or overnight, is clearly the most sensitive assay to measure urinary albumin excretion rate (UAER). Determination of albumin in a random urine specimen (RUS) is more practical and convenient than timed urine collection. Recently, recommendations for screening and diagnosis of diabetic nephropathy, with special reference to microalbuminuria, have been published. Measurement of urinary albumin concentration (UAC) (7) or urinary albumine creatinine ratio (UACR) (5-8) in an RUS or early
$200 \mu \mathrm{g} / \mathrm{min}$ or a UACR of $30-300 \mathrm{mg} / \mathrm{g}$ in an RUS, and macroalbuminuria is defined as a UAER > $200 \mu \mathrm{g} / \mathrm{min}$ or a UACR $>300 \mathrm{mg} / \mathrm{g}$. Although the cutoff points have been established in the consensus statement (5), there are very few data regarding the accuracy of the RUS to screen for diabetic nephropathy.

The receiver operating characteristics (ROC) curve has been used increasingly as a measurement of overall test performance $(10,11)$ and for comparison of the discriminating ability of clinical tests (12). The ROC curve analysis is based on the curve plotting the relationship between the true-positive rate (sensitivity) and the false-positive rate (100-specificity) over a range of cutoff points of a test.

This study was carried-out to assess the performance of UAC and UACR measurements in a diurnal RUS for screening of micro- and macroalbuminuria in patients with diabetes by using the ROC curve approach.

\section{Patients and methods}

This is a study of screening tests for microand macroalbuminuria. The criterion standard was 24-h UAER. The study was performed at the outpatient diabetes clinic at Hospital de Clínicas de Porto Alegre (a tertiary care center), between November 1994 and April 1995. Informed consent was obtained from each patient and the protocol was approved by the ethics committee.

Every NIDDM patient (World Health

Table 1 . Characteristics of the cutoff points of UAC and UACR as a screening test for micro- and macroalbuminuria in NIDDM patients ${ }^{\mathrm{a}}$

\begin{tabular}{lllll}
\hline & \multicolumn{2}{c}{ Microalbuminuria } & \multicolumn{2}{c}{ Macroalbuminuria } \\
\cline { 2 - 5 } & UAC mg/l & UACR mg/g & UAC mg/l & UACR mg/g \\
\hline Cutoff point & $16.9(33.6)$ & $15.0(26.8)$ & $174.0(296.2)$ & $116.0(334.3)$ \\
Sensitivity \% & $100(88.6)$ & $100(88.6)$ & $100(96)$ & $100(92)$ \\
Specificity \% & $79.6(88.9)$ & $74.1(88.9)$ & $86.4(93)$ & $56.8(90.9)$ \\
\hline
\end{tabular}

a Data are the first cutoff point with $100 \%$ sensitivity (the nearest point to the intersection of the curve with the $100 \%$-to- $100 \%$ diagonal).

morning urine sample $(6,9)$ have been recommended. According to the American Diabetes Association consensus statement (5), microalbuminuria is defined as a UAER of 20-
Organization criteria) without evidence of cardiac failure or renal tract disease other than diabetic nephropathy (urinary tract infection, hematuria abnormal urinary sediment, and/or plasma 

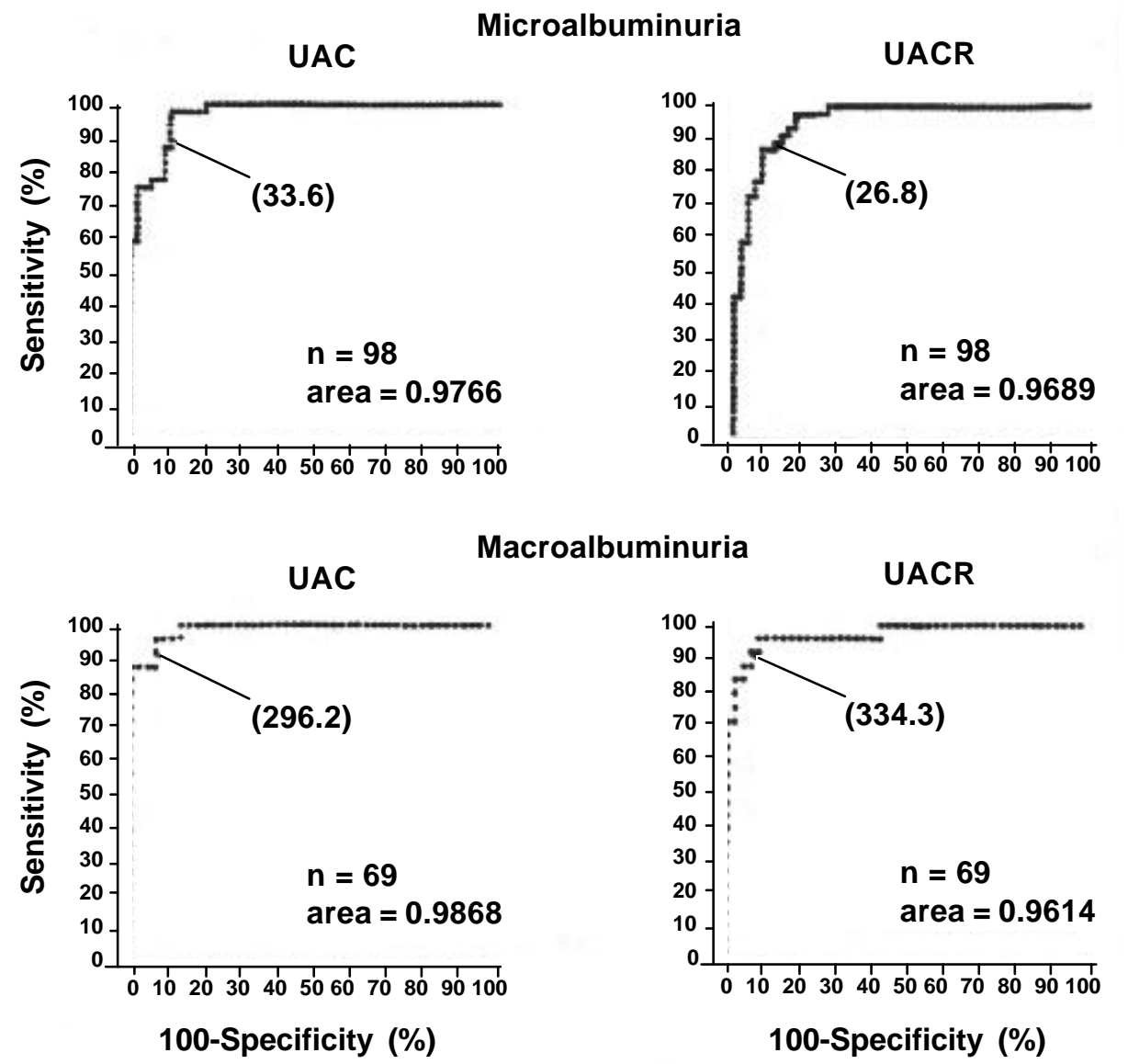

Figure 1. ROC curves for UAC and UACR as a screening test for microalbuminuria and macroalbuminuria. Values in parenthesis $(U A C=\mathrm{mg} /$; UACR $=\mathrm{mg} / \mathrm{g}$ ) correspond to the intersection of the curve with the $100 \%$-to $100 \%$ diagonal.

creatinine increase without proteinuria) was considered for the study. Ninety-five NIDDM outpatients (49 women), ages 40-75 years (60.6 \pm 8.5 years; mean $\pm S D$ ), with $1-45$ years of known diabetes duration (11.3 \pm 8.6 years), body mass index (BMI) of $18.2-41.0 \mathrm{~kg} / \mathrm{m}^{2}(27.7 \pm 4.3 \mathrm{~kg} /$ $\mathrm{m}^{2}$ ), and mean blood pressure of $70-147 \mathrm{mmHg}$ $(106.4 \pm 14.6 \mathrm{mmHg})$ were included. Their $\mathrm{HbA}$ ranged from 6.9 to $15.6 \%(10.1 \pm 2.1 \%)$, plasma creatinine from 0.6 to $2.3 \mathrm{mg} / \mathrm{dl}(1.05 \pm 0.3 \mathrm{mg} /$ $\mathrm{dl}$ ), and 24-h UAER from 0.13 to $4056.8 \mu \mathrm{g} / \mathrm{min}$ (median: $18.3 \mu \mathrm{g} / \mathrm{min}$ ). The patients were oriented to collect timed 24-h urine samples and to return on the morning after the end of urine collection. No specific recommendation was made about fluid intake, physical exercise, or dietary protein intake. Women were not examined during menstruation. At the time of this clinical visit, after an overnight fast, a blood sample was taken to measure biochemical parameters, and an RUS (after first urine voided in the morning) was taken for UAC and for UACR measurements. Urinary albumin was measured in duplicate by immunoturbidimetry (Microlab, Ames). At our laboratory, the mean intra- and interassay coefficients of variation are 4.5 and $11.0 \%$, respectively. $\mathrm{HbA}_{1}$ was analyzed by agarose gel electrophoresis (Celmgel; normal range: 6.0$9.2 \%$ ) and creatinine by Jaffé's reaction.

The patients collected 132 24-h UAER and 132 RUS. All urine samples were confirmed to be sterile by culture. The 24-h UAER was considered adequate when creatinine measurements in the same sample were confirmed to be sterile by culture. The 24-h UAER was considered adequate when creatinine measurements in the same sample were 700$1,500 \mathrm{mg}$ for women and 1,000-1,800 for men. Nine samples were excluded based on this criterion, two from women patients (441 and 556 $\mathrm{mg}$ ) and seven from men patients (701-980mg). Thus, 123 24-h UAER and 123 RUS were 
examined. Samples were divided into normoalbuminuric (UAER $<20 \mu \mathrm{g} / \mathrm{min}$; $\mathrm{n}=54$ ), microalbuminuric (UAER=20-200 $\mu \mathrm{g} / \mathrm{min} ; \mathrm{n}=44$ ), and macroalbuminuric (UAER > $200 \mu \mathrm{g} / \mathrm{min} ; \mathrm{n}=$ 25) groups, according to the criterion standard.

The relationship between UAER vs. UAC and UACR was calculated by Spearman's correlation coefficients (rS). Sensitivities and specificities of RUS measurements (UAC and UACR) as a screening test for microalbuminuria were calculated using normo- and microalbuminuric samples $(n=98)$ and for macroalbuminuria using micro- and macroalbuminuric samples $(n=69)$. The ROC curve approach was used to analyze the performance of the screening test. The truepositive rate (sensitivity) versus the false-positive rate (100-specificity) was plotted for each measurement. Sensitive tests are helpful to screen people without complaints, as is the case in the early stages of diabetic nephropathy. Thus, the first point with a sensitivity of $100 \%$ was chosen in each curve. A second cutoff point was also determined in each curve by the intersection of the curves with the 100\%-to-100\% diagonal. The latter point represents the best equilibrium between sensitivity and specificity. The statistical analyses of ROC curves were performed with a VisiCalc program (10), using the ROC analyzer software version 5.0 which calculates the area under the curve and the significance of differences between areas (12). The level of significance was set at 0.05 .

\section{Results}

Spearman's coefficients of correlation of 24-h UAER vs. UAC $(\mathrm{n}=123)$ and UACR ratio $(\mathrm{n}=123)$ were 0.91 and 0.92 respectively $(P<$ 0.001 ). Median values of 24-h UAER, UAC, and UACR were $42.7 \mu \mathrm{g} / \mathrm{min}, 42.3 \mathrm{mg} / \mathrm{min}$, and 44.2 $\mathrm{mg} / \mathrm{g}$ respectively.

Figure 1 depicts the ROC curves for UAC and UACR as a screening test for microalbuminuria. The areas (mean $\pm S E$ ) under the ROC curves for microalbuminuria were $0.9766 \pm 0.015$ for UAC and $0.9689 \pm 0.014$ for UACR. Corresponding areas for macroalbuminuria were $0.9868 \pm 0.0094$ and $0.9614 \pm 0.0241$, respectively. There was no statistical difference between calculated areas for
UAC and UACR for micro- or macroalbuminuria $(P>0.05)$. ROC curves for UAC and UACR as a screening test for micro- and macroalbuminuria were constructed separately for men and women (data not shown). The curves were skewed to the left from the $45^{\circ}$ diagonal and all the areas under the curves were $>0.9542$, without any difference in area between men and women $(P$ $>0.05$ ).

Table 1 presents the characteristics of the cutoff points for screening of micro- and macroalbuminuria according to the first point with a sensitivity of $100 \%$ and the nearest point to the intersection of the curves with the 100\%-to-100\% diagonal.

\section{Conclusions}

In this study, UAC and UACR measured in an RUS showed an excellent performance as a screening test for the diagnosis of both microand macroalbuminuria.

UAC and UACR presented a strong correlation with the 24-h UAER ( $r S>0.9$ ), over a wide range of UAC (24-h UAER of 0.13 - 4,056.8 $\mu \mathrm{g} / \mathrm{min}$ ), confirming data from other authors. In one study in which 25 diabetic patients were evaluated, albumin measured in single-void urine samples and expressed as $\mu \mathrm{g} / \mathrm{mg}$ creatinine had an excellent correlation with 24-h UAER $(r=$ $0.80)(13)$. In another study (14), albumin $(\mu \mathrm{g} / \mathrm{ml})$ was determined in 94 single-void random upright urine collections from patients with diabetes and correlated well with 24-h UAER $(r=0.79)$.

In the present study, the accuracy of UAC and UACR analyzed by area under the ROC curves was almost perfect for the screening of micro- and macroalbuminuria because the observed values varied from 0.9614 to 0.9868 . Similar accuracy was observed for women and men. The estimated area under the fitted smooth curve ranges from 0.5 (no apparent accuracy) to 1.0 (perfect accuracy) as the ROC curves moves toward the left and top boundaries of the ROC graph (11). The selection of the best diagnostic test is based on the statistical comparison of measurements of the area under the curve. Other authors used the ROC curve approach to analyze the performance of urinary albumin measurements, but not in RUS. One study (15) evaluated UAC $(\mu \mathrm{g} / \mathrm{ml})$ in spot urine samples 
during water-induced diuresis and night UAER against 24-h UAER in patients with diabetes. According to the authors, the ROC curve for spot concentration was displaced to the right as compared with the ROC curve for night UAER. This increase of false-positive results would be expected because of the known effect of water loading on the increase of urinary albumin (16). However, visual inspection of the curves suggests that any difference is minimal, but it is not possible to confirm that the curves are in fact different, because statistical data were not presented. In another study (17), the investigators analyzed UAC and UACR in a timed overnight urine collection and observed that the UACR outperformed UAC in detecting a UAER of 30 $\mu \mathrm{g} / \mathrm{min}$. Also in this study, the areas under the curves were not calculated, and the comparison between curves was performed only by visual inspection. In the present study no difference was observed when comparing the performance of UAC and UACR based on statistical comparison of measurements of the area under the ROC curves. UAC measurements have been considered less reliable because variation in urine flow rate might significantly influence the results. This was the case in one study that compared UAC and UAER measured in the same timed 12$\mathrm{h}$ nightly urine collection. The wide range of urine volumes (up to 3 liters) could explain the low sensitivity (70\%) of UAC at the level of $20 \mathrm{mg} /$ I (18). The better sensitivity observed in the present study is probably due to a lesser effect of dilution in one voided urine sample because of the limited capacity of the bladder.

The ROC curve allows the comparison of the sensitivity and specificity of a test over a wide range of cutoff points and the selection of the best diagnostic criterion for that test (11). Two criteria were used for the selection of cutoff points to diagnose micro- and macroalbuminuria: the first point with $100 \%$ sensitivity and the point that represents the best equilibrium between sensitivity and specificity. According to the latter criterion, the observed values of UACR of 26.8 $\mathrm{mg} / \mathrm{g}$ for the diagnosis of microalbuminuria and of $334.3 \mathrm{mg} / \mathrm{g}$ for the diagnosis of macroalbuminuria were very similar to the UACR values of 30 and $300 \mathrm{mg} / \mathrm{g}$, respectively, as recommended by the American Diabetes Association in a recent consensus statement (5).
As expected, corresponding values (15 and 116 $\mathrm{mg} / \mathrm{g}$, respectively) were lower when the $100 \%$ sensitivity criterion was used. Other authors also described lower values of UACR for the diagnosis of microalbuminuria. In a recent study (8), albumin (UACR) was measured in a random daytime urine sample. A lower boundary between normoalbuminuria and microalbuminuria was described, both for women $(17 \mathrm{mg} / \mathrm{g})$ and for men $(25 \mathrm{mg} / \mathrm{g})$. According to the investigators, these values corresponded to the 95th percentiles of the respective distributions of the UACR in healthy control subjects. The adoption of lower cutoff points to diagnose diabetic nephropathy, at least regarding the screening for microalbuminuria, could be relevant. Recent data from prospective studies suggest that UAER values $<20 \mu \mathrm{g} / \mathrm{min}$ (median: $15.7 \mu \mathrm{g} / \mathrm{min} ; 17 \mathrm{mg} /$ 24-h or $11.8 \mu \mathrm{g} / \mathrm{min}$ ) could already be associated with the transition from normoalbuminuria to macroalbuminuria in IDDM patients (19). Also, in a 5-year prospective study with normoalbuminuric NIDDM patients, the geometric mean value of UAER of $6.8 \mu \mathrm{g} / \mathrm{min}$, although still in the normal range, was related to later development of microalbuminuria (20).

In conclusion, albumin measurements (UAC and UACR) in an RUS presented almost perfect accuracy for the screening of micro- and macroalbuminuria in NIDDM patients, and UAC measured in an RUS is simpler and less expensive than UACR and UAER. It is suggested as a valid test for use in screening for diabetic nephropathy.

Acknowledgments. This study was supported by grants from Fundação de Amparo à Pesquisa do Rio Grande do Sul(FAPERGS) and Hospital de Clínicas de Porto Alegre. T.Z. is the recipient of a scholarship from Coordenação de Aperfeiçoamento do Pessoal de Nível Superior (CAPES ), and AP and MT are the recipients of scholarships from Conselho Nacional de Desenvolvimento Científico e Tecnológico (CNPq).

Parts of this study were presented as an abstract at the 56th Annual Meeting of the American Diabetes Association, San Francisco, CA, June 8-11, 1996. 


\section{References}

1. Eggers PW. Effect of transplantation on the Medicare end-stage renal disease program. $N$ Engl J Med 1988;318:223-9.

2. Jarret RJ, Viberti GC, Argyropoulos A, Hill RD, Mahmud U, Murrels TJ. Microalbuminuria predicts mortality in non-insulin dependent diabetes. Diabet Med 1984;1:17-9.

3. Mattock MB, Keen H, Viberti GC, Murrels TJ, Scott GS, Wing JR, et al. Coronary heart disease and urinary albumin excretion rate in type 2 (non-insulin dependent) diabetic patients. Diabetologia 1988;31:82-7.

4. Defronzo R. Diabetic nephropathy: ethiologic and therapeutic considerations. Diabetes Reviews 1995;3:510-64.

5. American Diabetes Association. Consensus development conference on the diagnosis and management of nephropathy in patients with diabetes mellitus Consensus statement). Diabetes Care 1994;17:1357-61.

6. Bennet PH, Haffner S, Kasiske BL, Keane WF, Mogensen $\mathrm{CE}$, Parving $\mathrm{HH}$, et al. Screening and management of microalbuminuria in patients with diabetes mellitus: recommendations to the Scientific Advisory Board of the National Kidney Foundation from Ad Hoc Committee of the Council on Diabetes Mellitus of the National Kidney Foundation. Am J Kidney Dis 1995;25:107-12.

7. International Diabetes Federation, Saint Vincent's Declaration, World Health Organization. Consensus Guidelines for the Management of InsulinDependent (Type I) Diabetes. Medicom Europe BV, Ed. Bussum, The Netherlands, European IDDM Police Group, 1993

8. Waram JH, Gearin G, Laffel L, Krolewski AS. Effect of type I diabetes on the prevalence of stages of diabetic nephropathy defined by urinary albumin creatinine ratio. J Am Soc Nephrol 1996;7:1-8.

9. Mogensen CE, Vestbo E, Poulsen PL, Christiansen $C$, Damsgaard EM, Eiskjaer $\mathrm{H}$, et al. Microalbuminuria and the potential confounders: a review and some observations on variability of urinary albumin excretion. Diabetes Care 1995;18:572-81.
10. Centor RM: A Visicalc program for estimating the area under a receiver operating characteristic (ROC) curve. Med Decis Making 1985;5:139-48.

11. Hanley JA, McNeil BJ. The meaning and use of the area under a receiver operating characteristic (ROC) curve. Radiology 1982;143:29-36.

12. Hanley JA, McNeil BJ. A method of comparing the areas under receiver operating characteristic curves derived from the same cases. Radiology 1983; 148:839-43.

13. Nathan DM, Rosenbaum C, Protasowicki VD. Single-void urine samples can be used to estimate quantitative microalbuminuria. Diabetes Care 1987;10:414-18.

14. Shawab J, Dunn L, Feinglos N. Screening for microalbuminuria: a comparison of single sample methods of collection and techniques of albumin analysis. Diabetes Care 1992;15:1581-4.

15. Wiegmann TB, Chonko AM, Barnard MJ, MacDougall ML, Folscroft J, Stephenson J, et al. Comparison of albumin excretion rate obtained with different times of collection. Diabetes Care 1990;13:864-71.

16. Viberti GC, Mogensen CE, Keen H. Urinary excretion of albumin in normal man: the effects of water loading. Scand J Clin Lab Invest 1982;42:14751.

17. Connel SJ, Hollis S, Tieszen KL, McMurray JR, Dornan TI. Gender and the clinical usefulness of the albumin:creatinine ratio. Diabet Med 1994;11:32-6.

18. Kouri TT, Vikari JSA, Mattila KS, Irjala KMA. Microalbuminuria: invalidity of simple concentrationbased screening tests for early nephropathy due to urine volumes of diabetic patients. Diabetes Care 1991;14:591-3.

19. Mathiensen ER, Rönn B, Storm B, Fogth H, Deckert $\mathrm{T}$. The natural course of microalbuminuria in insulin-dependent diabetes: a 10-year prospective study. Diabet Med 1995;12:482-7.

20. Silveiro SO, Friedman R, Azevedo MJ, Canani LH, Gross JL. Five-year prospective study of glomerular filtration rate and albumin excretion rate in normofiltering and hyperfiltering normoalbuminuric NIDDM patients. Diabetes Care 1996;19:171-4. 